Ekonomis: Journal of Economics and Business, 5(1), Maret 2021, 202-208

Publisher: Lembaga Penelitian dan Pengabdian kepada Masyarakat Universitas Batanghari Jambi

Address: Jl. Slamet Ryadi, Broni-Jambi Kodepos: 36122

Website: http://ekonomis.unbari.ac.id, email: ekonomis.unbari@gmail.com

ISSN 2597-8829 (Online), DOI 10.33087/ekonomis.v5i1.299

\title{
Pengaruh Penjualan, Hutang Lancar, Modal Kerja dan Perpurtaran Persediaan Terhadap Laba Bersih pada Perusahaan Industri Barang Konsumsi di Bursa Efek Indonesia Periode 2014-2018
}

\author{
Nina Purnasari*, Micelle Shelina, Ferdinand Lumbantobing, Erika Sirait, Jan Evanyias Pasaribu \\ Universitas Prima Indonesia, Jl.Sekip, Petisah Tengah, Kota Medan \\ *Correspondence email: ninaunpri@gmail.com
}

\begin{abstract}
Abstrak. Tujuan dari penelitian ini yaitu guna memahami pengaruh modal kerja, penjualan, hutang lancar,serta perputaran persediaan atas keuntungan bersih di perusahaan sektor industri barang konsumsi yang tercatat dalam BEI periode 2014-2018. Metode penelitian ini berupa kuantitatif, dengan jenis penelitian deskriptif kuantitatif. Populasi penelitian ini yakni semua perusahaan sektor industri barang konsumsi yang tercatat dalam BEI berjumlah 23 perusahaan. Sampel penelitian ini yakni sejumlah 115 data, menggunakan teknik sampling berupa purposive sampling. Metode analisis memakai metode regresi linier berganda yang memanfaatkan uji F serta uji T serta koefisien determinasi didapat nilai Adjusted $R$ Square berarti varian variabel laba bersih yang bisa diterangkan variasi variabel penjualan, hutang lancar, perputaran persediaan serta modal kerja adalah dijelaskan oleh variabel bebas lainnya, dengan pengujian asumsi klasik yang mengunakan SPSS 23. Hasil yang didapat yaitu secara parsial penjualan, hutang lancar dan modal kerja memberikan pengaruh signifikan serta positif atas laba bersih dan perputaran persediaan tidak memberikan pengaruh pada laba bersih perusahaan industri barang konsumsi yang tercatat pada BEI tahun 2014-2018. Dengan cara simultan modal kerja, penjualan, hutang lancar, serta perputaran persediaan memberikan pengaruh signifikan pada keuntungan bersih perusahaan industri barang konsumsi yang tercatat pada BEI tahun 2014-2018.
\end{abstract}

Kata kunci : Hutang Lancar; Laba Bersih; Modal Kerja; Penjualan; Perputaran Persediaan

\begin{abstract}
The objective of the study is to test and analyze the effect of sales, current liabilities, working capital and inventory circulation on the net profit of industry consumption goods listed in the Indonesia Stock Exchange in the period of 2014- 2018. The research used in a quantitative research approach and the nature of this research is a causal research. The research populations were all companies of industry consumption listed on the Indonesia Stock Exchange totaling 23 companies. The research sample were 115 data, drawn by purposive sampling technique. The research data were analyzed by using multiple regression analysis using $F$ test and the $T$ test and the coefficient of determination was obtained by the value of adjusted $R$ Square meaning that the variations in variables of sales, current liabilities, working capital and inventory circulation, while were explained by other independent variables, by testing the classic assumption using SPSS 23. The research finding showed that partially sales, current liabilities and working capital had a significant effect on net income while inventory circulation had no effect to net income in industry consumption goods listed in the Indonesia Stock Exchange in the period 2014- 2018. Simultaneosly sales, current liabilities, working capital, inventory goods had a significant effect on net income in industry consumption goods listed in Indonesia Stock Exchange (IDX) period 2014-2018.
\end{abstract}

Keywords : Current Liabilities; Inventory Circulation; Net Profit; Sales; Working Capital

\section{PENDAHULUAN}

Era perekonomian sekarang banyak perusahaan-perusahaan bersaing keras untuk mendapatkan investor. Investor ingin berinvestasi jika perusahaan tersebut memiliki laba yang baik dan laporan keuangan yang lengkap. Salah satu sektor yang mampu bertahan pada era krisis global pertengahan tahun 2008 yaitu, sektor industri barang konsumsi. Bidang industri barang konsumsi berperan penting bagi pertumbuhan ekonomi di Indonesia. Sektor ini tidak akan pernah mati karena sektor ini merupakan bahan pangan yang dipakai sehari-hari oleh seluruh masyarakat, sehingga sektor ini mampu bertahan para era krisis global. Sektor ini juga telah mengalami banyak pertumbuhan ekonomi yang cukup baik pada saat ini.

Pada setiap perusahaan pasti akan berusaha meningkatkan laba bersihnya, permasalahannya banyak perusahaan belum mampu meningkatkan laba bersih, sehingga perusahaan tersebut mengalami kerugian karena perusahaan tidak mampu bersaing dengan perusahaan lain. Laba bersih sangat di perlukan oleh perusahaan supaya para investor dapat melihat apakah perusahaan tersebut mengalami laba ataupun rugi.Dalam meningkatkan laba bersih, sangat penting di tingkatkan juga penjualan karena, akan mempengaruhi daya saing serta menurunkan berbagai biaya guna meraih laba bersih yang optimal. Tetapi masih banyak perusahaan yang belum mampu dalam meningkatkan penjualan. Dalam menjalankan usaha, proses penjualan juga menjadi pendukung laporan keuangan.Permasalahan selanjutnya adalah hutang pada perusahaan yang mengakibatkan laba bersih mengalami kerugian karena ketidakmampuan perusahaan untuk membayar hutangnya dengan baik. Hutang menjadi sebuah masalah, karena perusahaan harus mampu untuk 
membayarnya. Banyak perusahaan yang memiliki hutang berjumlah besar cenderung beresiko besar pula untuk perusahaan.

Pada perusahaan modal juga sangat penting dalam meningkatkan laba bersih. Tetapi masih banyak yang kurang dalam pengelolaan modal kerja, mengakibatkan penurunan pada laba bersih. Modal kerja yang kurang membiayai kegiatan operasional pada perusahaan dapat memunculkan kerugian untuk perusahaan sebab modal kerja tersebut tidak dapat digunakan guna mendapatkan laba yang lebih besar.Kemudian perputaran persediaan juga diperlukan perusahaan agar dapat memutarkan modal usaha dan dapat meningkat laba perusahaan. Permasalahan yang sering kali terjadi, dimana barang yang dijual mempersedikit persediaan namun laba perusahaan ikut menurun.

Berdasarkan hasil dari penelitian laporan keuangan di BEI (sumber : www.idx.com), peneliti menemukan bahwa penjualan pada perusahaan PYFA pada tahun 2015 sebesar Rp 217.843.921.422.000 telah mengalami penurunan dibandingkan pada tahun 2014 dengan laba pada tahun 2015 sebesar Rp 3.087.104.465.000 yang mengalami peningkatan dari tahun 2014. Penjualan yang menurun seharusnya dapat menurunkan laba namun pada kenyataannya penjualan yang menurun justru meningkatkan laba perusahaan.

Perusahaan KAEF memiliki hutang lancar pada tahun 2017 sejumlah Rp 2.369.507.448.768 telah meningkat dari pada tahun 2016 dengan laba pada tahun 2017 sejumlah Rp 331.707.917.461 yang juga mengalami peningkatan dari tahun 2016. Hutang lancar yang mengalami peningkatansecara umum harus bisa menurunkan laba namun pada kenyataannya hutang lancar yang meningkat justru meningkatkan laba perusahaan.Perusahaan WIIM memiliki nilai modal kerja pada tahun 2016 sebesar Rp 703.213.310.580 telah meningkat daripada tahun 2015 dengan laba pada tahun 2016 sejumlah Rp106.290.306.868 yang mengalami penurunan dari tahun 2015. Modal kerja yang meningkat seharusnya dapat meningkatkan laba namun pada kenyataannya modal kerja yang meningkat justru menurunkan laba perusahaan. Perusahaan TCID memiliki perputaran persediaan pada tahun 2017 sebesar Rp 422.625.745.680 telah mengalami penurunan dibandingkan pada tahun 2016 yang memiliki laba di tahun 2017 sejumlah 179.126.382.068 dan meningkat dari tahun 2016. Perputaran persediaan yang menurun seharusnya dapat menurunkan laba namun pada kenyataannya perputaran persediaan yang menurun justru meningkatkan laba perusahaan.

\section{Teori Pengaruh Penjualan Terhadap Laba Bersih}

Menurut Budi Rahardjo (2016) bahwa terdapatnya korelasi yang erat terkait penjualan atas pertumbuhan keuntungan bersih perusahaan, dimana hal ini bisa diketahui melalui laporan laba rugi perusahaan, sebab keuntungan akan didapat apabila penjualan produknya melebihi modal-modalyang dikeluarkan. Faktor pokok yang memengaruhi taraf keuntungan yakni pendapatan, pendapatan bisa didapat melalui hasil penjualan produk ataupun jasa yang dijual.

\section{Teori Pengaruh Hutang Lancar Terhadap Laba Bersih}

Sesuai pemaparan Nafarin (2013), memperbanyak hutang jangka panjang, modal sendiri, serta hutang jangka pendek bertujuan untuk ekspansi, yakni mengembangkan kegiatan perusahaan, memperluas kegiatan pemasaran, dan memperluas kegiatan produksi guna mendapat laba semaksimal mungkin. Melalui peningkatan kegiatan pemasaran dan produksi sebagai konsekuensi peningkatan pembelanjaan dengan modal sendiri dan hutang bisa memperbesar laba.

\section{Teori Pengaruh Modal Kerja Terhadap Laba Bersih}

Hani(2015) memberi penjelasan, modal kerja adalah susunan paling penting pada kegiatan operasional perusahaan, modal kerja menunjukkan potensi perusahaan dalam melakukan pengelolaan terhadap pembiayaan perusahaan, melalui pemanfaatan pendanaan yang dimilikinya maka diharapkan produktivitasnya juga bisa berjalan lancar. Modal kerja yang bertambah tinggi maka diharapkan produktivitasnya akan mengalami peningkatan sehingga keuntungan juga terus meningkat.

\section{Teori Pengaruh Perputaran Persediaan Terhadap Laba Bersih}

Sesuai pemaparan Bambang Riyanto (2011) dimana menjelaskan, permasalahan terkait penentuan besarnya alokasi modal atau investasi dalam persediaan berefek langsung pada laba perusahaan. Penetapan besarnya investasi dalam inventori yang salah akan menurunkan laba perusahaan.

\section{METODE}

Menurut Sugiyono (2012) bahwa pendekatan penelitian memanfaatkan teknik penelitian kuantitatif, yaitu penelitian yang berdasar kepada filsafat postivisme, dimanfaatkan guna melakukan penelitian terhadap suatu sampel atau populasi, teknik samplingnya dilakukan secara random, dengan pengumpulan datanya memanfaatkan alat ukur penelitian, analisis data memiliki sifat kuantitatif atau statistik yang memiliki tujuan guna melakukan pengujian terhadap hipotesis yang sudah ada.Jenis penelitian berupa penelitian deskriptif. Sesuai pemaparan Sugiyono (2012) bahwa jenis penelitian ini adalah penelitian deskriptif, yakni penelitian yang tidak membandingkan variabel penelitian 
pada sampel yang lainnya, serta menemukan hubungan variabel penelitian.Populasi penelitian ini yakni perusahaan sektor industri barang konsumsi yang tercatat pada BEI periode 2014-2018 berjumlah 35 perusahaan.

Teknik dokumentasi ialah teknik yang dipakai pada penelitian ini. Teknik ini dijalankan dengan cara pengumpulan data sekunder melalaui laporan keuangan tahunan perusahaan Industri Barang Konsumsi tahun 20142018.Jenis data sekunder adalah jenis data penelitian ini. Sumber data didapatkan melalui laporan keuangan perusahaan Industri Barang Konsumsi yang tercatat di BEI dengan website www.idx.co.id

\section{Teknik Analisis Data Uji Asumsi Klasik}

Sesuai pemaparan Ghozali (2013), tujuan uji ini yakni guna mengetahui apakah pada model regresi, variabel pengganggu berdistribusi normal. Dipahami bila uji $\mathrm{f}$ serta uji t mengasumsikan jika nilai residual menyertai distribusi normal. Uji normalitas penelitian dengan statistik non-parametik Kolmogorov SmirnovTest.Uji multikolinearitas yakni guna melakukan pengujian terkait apakah model regresi ada korelasi antara variabel bebas. Berdasarkan uji terdapat ataukah tidak multikolinearitas dapat diamati melalui Variance Inflation Factorserta nilai Tolerance.Uji Autokorelasi untuk melihat apakah pada model regresi antara kesalahan penganggu di periode t- 1 dan kesalahan pengganggu di periode t. Sebuah ukuran guna menentukan terdapat ataukah tidak autokorelasi yakni dengan uji Durbin-Watson.Heteroskedastisitas merupakan kondisi yaitu ketidakselarasan varian melalui residual guna seluruh pengamatan dalam model regresi. guna menguji adanya suatu heteroskedastisitas dapat dideteksi menggunakan Uji Glejser.

\section{Uji Hipotesis}

Sesuai pemaparan Ghozali (2013:98), Uji F yaitu membuktikan apakah semua variabel independen yang dimasukkan ke model berpengaruh dengan berssama-sama atas variabel dependen. Uji t padadasarnya membuktikan sejauh mana pengaruh suatu variabel penjelas dengan cara individual saat menjelaskan variasi variabel dependen.

\section{Hasil}

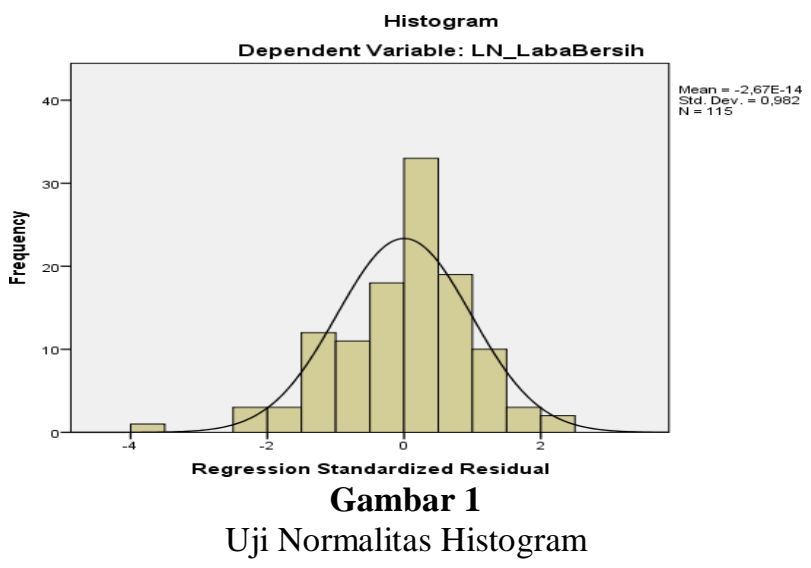

Gambar 1 memperlihatkan setelah transformasi data sudah memiliki distribusi normal sebab visual grafik memiliki bentuk simetris tidak melenceng ke kiri ataupun ke kanan.Kecuali histogram asumsi normalitas dapat pula diamati melalui grafik P-Plot.

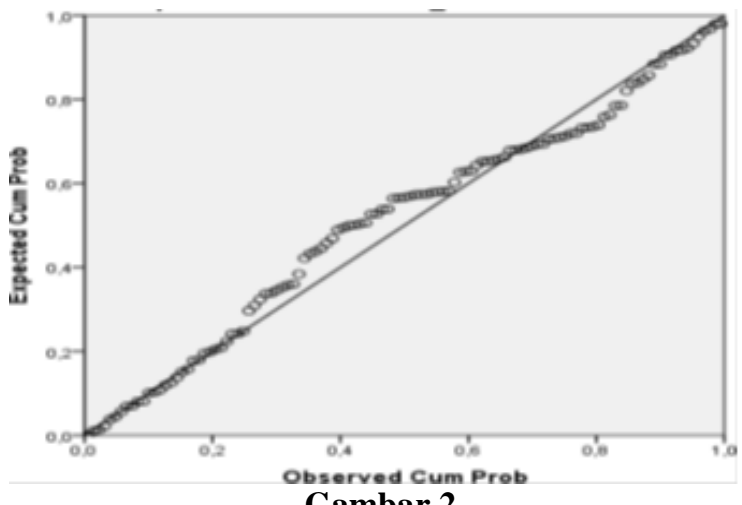

Gambar 2

Uji Normalitas P-P Plot 
Nina Purnasari, Micelle Shelina, Ferdinand Lumbantobing,Erika Sirait dan Jan Evanyias Pasaribu, Pengaruh Penjualan, Hutang Lancar, Modal Kerja dan Perpurtaran Persediaan Terhadap Laba Bersih pada Perusahaan Industri Barang Konsumsi di Bursa Efek Indonesia Periode 2014-2018

Gambar 2 diamati titik-titik itu bergerak mendekati serta mengikuti garis diagonal serta kemudian menunjukkan data itu sudah memiliki distribusi normal.

Tabel 1

Hasil Uji Kolmogorov Smirnov

\begin{tabular}{|c|c|c|}
\hline & & $\begin{array}{l}\text { Unstandardiz } \\
\text { ed Residual }\end{array}$ \\
\hline $\mathrm{N}$ & & 115 \\
\hline \multirow[t]{2}{*}{ Normal Parameters ${ }^{a \cdot b}$} & Mean &, 0000000 \\
\hline & Std. Deviation &, 65887654 \\
\hline \multirow[t]{3}{*}{ Most Extreme Differences } & Absolute & .097 \\
\hline & Positive & .066 \\
\hline & Negative & -.097 \\
\hline Kolmogorov-Smirnov Z & & 1,046 \\
\hline Asymp. Sig. (2-tailed) & & .224 \\
\hline
\end{tabular}

Sumber: data olahan

Hasil dari uji di atas menunjukkan nilai signifikansi dimana nilai Asymp.Sig (2-tailed) sejumlah 0,224>0,05 dan kemudian bisa ditarik kesimpulan jika data tersebut sudah memiliki distribusi normal.

Tabel 2

Uji Multikolinearitas

\begin{tabular}{|ll|r|r|}
\hline \multirow{2}{*}{ Model } & \multicolumn{2}{|c|}{ Collinearity Statistics } \\
\cline { 3 - 4 } & & Tolerance & \multicolumn{1}{l|}{ VIF } \\
\hline 1 & LN_Penjualan &, 542 & 1,846 \\
& HutangLancar &, 864 & 1,158 \\
& ModalKerja &, 580 & 1,724 \\
& PerputaranPersediaan &, 842 & 1,187 \\
\hline
\end{tabular}

Sumber: data olahan

Hasil pengujian Multikolinearitas menunjukkan nilai tolerance variabel Penjualan, Hutang Lancar, Modal Kerja dan Perputaran Persediaan di atas 0,10 serta nilai VIF variabel Penjualan, Hutang Lancar, Modal Kerja, dan Perputaran Persediaan di bawah 10. Sehingga dapat disimpulkan hasil dari ini tidak terdapat regresi antar variabel independen.

Tabel 3

Uji Autokorelasi

\begin{tabular}{|l|c|r|r|r|r|}
\hline \hline Model & $R$ & R Square & $\begin{array}{c}\text { Adjusted R } \\
\text { Square }\end{array}$ & $\begin{array}{c}\text { Std. Error of } \\
\text { the Estimate }\end{array}$ & $\begin{array}{c}\text { Durbin- } \\
\text { Watson }\end{array}$ \\
\hline 1 &, $978^{2}$ &, 956 &, 954 &, 67075 & 2,230 \\
\hline \hline
\end{tabular}

Sumber: data olahan

Dengan melihat pedoman pada tabel Durbin Watson untuk k (jumlah variabel X) $=4$ dan $\mathrm{n}$ (jumlah data) $=115$ maka: $\mathrm{dL}=1,6246 ; 4-\mathrm{dL}=2,3754$ dandU $=1,7683 ; 4-\mathrm{dU}=2,2317$; sehingga hasil dari uji Durbin Watson memenuhi kriteria ke-5 yaitu $\mathrm{dU}<\mathrm{d}<4-\mathrm{dU} / 1,7683<2,230<2,2317$ yang artinya tidak ada autokorelasi negatif ataupun positif dalam penelitian ini. 
Nina Purnasari, Micelle Shelina, Ferdinand Lumbantobing,Erika Sirait dan Jan Evanyias Pasaribu, Pengaruh Penjualan, Hutang Lancar, Modal Kerja dan Perpurtaran Persediaan Terhadap Laba Bersih pada Perusahaan Industri Barang Konsumsi di Bursa Efek Indonesia Periode 2014-2018

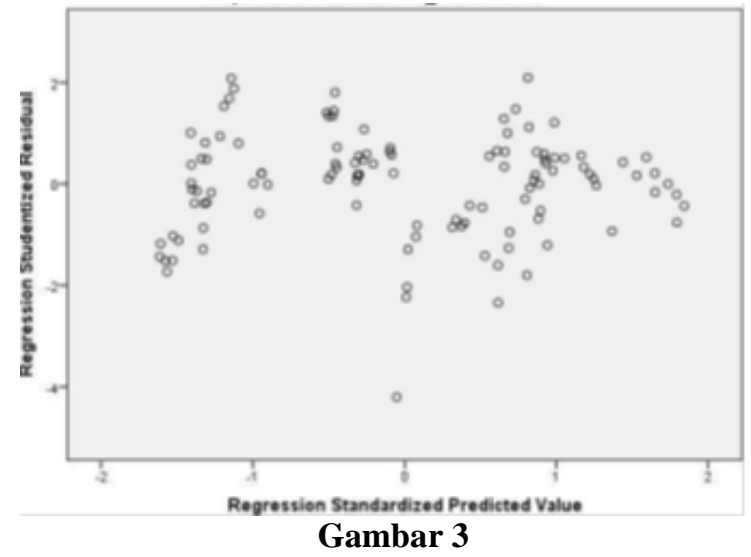

Uji Heteroskedastisitas

Hasil uji grafik di atas data menunjukkan plot telah tersebar secara acak sehingga data di penelitian ini telah selaras pada syarat uji asumsi klasik karena tidak terdapat heteroskedastisitas.

Tabel 4

Uji Spearman's rho

\begin{tabular}{|c|c|c|c|c|c|c|c|}
\hline & & & UU Penuasan & Hotanglancar & Modalesta & $\begin{array}{l}\text { Perputaran } \\
\text { Persediaga }\end{array}$ & $\begin{array}{c}\text { Unstandartewed } \\
\text { Resideal }\end{array}$ \\
\hline \multirow{15}{*}{$\begin{array}{l}\text { Spexmans } \\
\text { ithe }\end{array}$} & \multirow[t]{3}{*}{ Uu Parivalan } & Cornalabse Cethiciert & 1,000 & .026 & $.927^{\prime \prime}$ & $260^{\prime \prime}$ & 819 \\
\hline & & Sia Craind & & 784 & .000 & .005 & $\mathbf{m 4}$ \\
\hline & & n & 115 & 115 & 115 & 115 & 115 \\
\hline & \multirow[t]{3}{*}{ Helang Luncat } & Cortulabien Ceethciert & .026 & 1.000 & $261 "$ & $-506^{\prime \prime}$ & -.050 \\
\hline & & Sia Cotaind & 724 & & .002 & .000 & sin \\
\hline & & $n$ & 115 & 115 & 115 & 115 & 115 \\
\hline & \multirow[t]{3}{*}{ Modakcasa } & Contelabse Ceefficiert & $.927^{\prime \prime}$ & $281^{\prime \prime}$ & 1,000 & .092 & -076 \\
\hline & & sia C-aied & .000 & .002 & & $\pi 35$ & 407 \\
\hline & & n & 115 & 115 & 115 & 115 & 115 \\
\hline & \multirow{3}{*}{$\begin{array}{l}\text { Powularan } \\
\text { Perredaan }\end{array}$} & Contelabso Centicien & $260^{\prime \prime}$ & .506 & .092 & 1,000 & .113 \\
\hline & & Sis Qtaied & .905 & .000 & $n s$ & & 231 \\
\hline & & $n$ & 115 & 115 & 115 & 115 & 115 \\
\hline & \multirow{3}{*}{$\begin{array}{l}\text { Unatundartited } \\
\text { Retious }\end{array}$} & Contabson Ceeficiere & 019 & .050 & -070 & .113 & \multirow[t]{2}{*}{1,000} \\
\hline & & sig cotated & $M 4$ & $2 n$ & 487 & 231 & \\
\hline & & $w$ & 115 & 115 & 115 & 115 & 115 \\
\hline
\end{tabular}

Sumber: data olahan

Hasil uji spearmans' rho, memperlihatkan data pada penelitian ini tidak terdapat heteroskedastisitas karena nilai signifikan dari empat variabel bebas/X1 sampai X4 lebih besar dari batas nilai signifikan yang ditentukan yaitu lebih besar dari 0.05 .

\section{Analisi Regresi Linear Berganda}

Tabel 5

Persamaan Analisis Regresi Linear Berganda

\begin{tabular}{|c|c|c|c|c|c|}
\hline \multirow[b]{2}{*}{ Model } & \multicolumn{2}{|c|}{$\begin{array}{l}\text { Unstandardized } \\
\text { Coefficients }\end{array}$} & \multirow{2}{*}{$\begin{array}{c}\text { Standardized } \\
\text { Coefficients }\end{array}$} & \multirow[b]{2}{*}{$t$} & \multirow[b]{2}{*}{ Sig. } \\
\hline & B & Std. Error & & & \\
\hline $\begin{array}{ll}1 & \text { (Constant) }\end{array}$ & 2,248 & 801 & & 2,807 & .006 \\
\hline LN_Penjualan & ,837 & 025 & 915 & 33,705 &, 000 \\
\hline HutangLancar & , 101 & .035 & .062 & 2,896 &, 005 \\
\hline ModalKerja &, 000 &, 000 &, 106 & 4,042 &, 000 \\
\hline PerputaranPersediaan & .009 & .013 & .015 & 689 & 492 \\
\hline
\end{tabular}

Sumber: data olahan

Persamaan regresi berganda pada penelitian ini yaitu:

LN_Laba Bersih $=2,248+0,837$ LN_Penjualan + 0,101 Hutang Lancar + 0,000 Modal Kerja + 0,009 Perputaran Persediaan 
Nina Purnasari, Micelle Shelina, Ferdinand Lumbantobing,Erika Sirait dan Jan Evanyias Pasaribu, Pengaruh Penjualan, Hutang Lancar, Modal Kerja dan Perpurtaran Persediaan Terhadap Laba Bersih pada Perusahaan Industri Barang Konsumsi di Bursa Efek Indonesia Periode 2014-2018

Hasil persamaan ini dapat dipaparkan seperti di bawah ini:

1. Konstanta (a) sebesar 2,248 berarti apabila variabel X yakni konstan/tetap atau bernilai 0 maka laba bersih akan bernilai 2,248 satuan. Dan asumsi variabel $\mathrm{X}$ yang lain adalah konstan.

2. b1X1 sebesar 0,837 berarti setiap kenaikan penjualan sebanyak 1 satuan akan menyebabkan peningkatan pada laba bersih sebanyak 0,837 satuan. Dan asumsi variabel $X$ yang lain adalah konstan.

3. b2X2 senilai 0,101 artinya setiap kenaikan hutang lancar sebanyak 1 satuan akan menjadikan peningkatan hutang lancar senilai 0,101 satuan. Dan asumsi variabel $\mathrm{X}$ yang lain yaitu konstan.

4. b3X3 senilai 0,000 artinya setiap peningkatan modal kerja sebanyak 1 satuan akan menjadikan peningkatan keuntungan bersih senilai 0,000 satuan. Dan asumsi variabel $\mathrm{X}$ lainnya yaitu konstan.

5. b4X4 senilai 0,009 artinya setiap peningkatan perputaran persediaan sebanyak 1 satuan akan menjadikan peningkatan pada keuntungan bersih sejumlah 0,009 satuan. Dan asumsi variabel X lainnya adalah konstan.

Tabel 6

Uji Koefisien Determinasi

\begin{tabular}{|l|l|r|r|r|}
\hline Model & R & R Square & $\begin{array}{c}\text { Adjusted R } \\
\text { Square }\end{array}$ & $\begin{array}{c}\text { Std. Error of } \\
\text { the Estimate }\end{array}$ \\
\hline 1 &, $978^{\text {a }}$ &, 956 &, 954 &, 67075 \\
\hline
\end{tabular}

Sumber: data olahan

Banyaknya pengaruh melalui semua variabel X pada variabel dependen diamati melalui nilai Adjusted R Square sejumlah 0,954 artinya sebesar 95,4\% dari variasi keuntungan bersih yang bisa dipaparkan oleh variabel perputaran persediaan, penjualan, hutang lancar, serta modal kerja dimana sisanya senilai 4,6\% dipengaruhi faktor lainnya misalnya variabel biaya operasional, total hutang, perputaran kas, dan variabel lainnya.

Tabel 7

Uji F

\begin{tabular}{|ll|r|r|r|r|r|}
\hline \multicolumn{1}{|c|}{} & \multicolumn{1}{|c|}{$\begin{array}{l}\text { Sum of } \\
\text { Model }\end{array}$} & Squares & df & Mean Square & \multicolumn{1}{c|}{ F } & Sig. \\
\hline 1 & Regression & 1077,253 & 4 & 269,313 & 598,601 &, $000^{6}$ \\
& Residual & 49,489 & 110 &, 450 & & \\
& Total & 1126,743 & 114 & & & \\
\hline
\end{tabular}

Sumber: data olahan

Besarnya nilai $\mathrm{F}$ tabel untuk df $1=4$ dan df $2=110$ yaitu sebesar 2,45 . Dengan melihat hasil uji $\mathrm{F}$ diperoleh nilai $\mathrm{F}$ hitung $(598,601)>\mathrm{F}$ tabel 2,45 serta nilai signifikan $0,000<0,05$ sehingga Ho tidak diterima serta Ha diterima yang berarti (penjualan, hutang lancar, perputaran persediaan, serta modal kerja) dengan cara bersamaan memberikan pengaruh signifikan pada keuntungan bersih perusahaan industri barang konsumsi yang tercatat pada Bursa Efek Indonesia tahun 2014-2018.

Tabel 8

Uji t

\begin{tabular}{|c|c|c|c|c|c|}
\hline \multirow[b]{2}{*}{ Model } & \multicolumn{2}{|c|}{$\begin{array}{c}\text { Unstandardized } \\
\text { Coefficients }\end{array}$} & \multirow{2}{*}{$\begin{array}{c}\begin{array}{c}\text { Standardized } \\
\text { Coefficients }\end{array} \\
\text { Beta } \\
\end{array}$} & \multirow[b]{2}{*}{$t$} & \multirow[b]{2}{*}{ Sig. } \\
\hline & $\mathrm{B}$ & Std. Error & & & \\
\hline $\begin{array}{ll}1 & \text { (Constant) }\end{array}$ & 2,248 & 801 & & 2,807 &, 006 \\
\hline LN_Penjualan & 837 &, 025 & ,915 & 33,705 &, 000 \\
\hline HutangLancar & , 101 &, 035 &, 062 & 2,896 &, 005 \\
\hline ModalKerja &, 000 &, 000 &, 106 & 4,042 &, 000 \\
\hline PerputaranPersediaan &, 009 & 013 & .015 & .689 & 492 \\
\hline
\end{tabular}

Sumber: data olahan

Besarnya t tabel dalam alpha 0,05 (two-tailed), df 110 yaitu 1,98177. Dengan membandingkan hasil uji secara parsial tersebut dengan besarnya t tabel maka : 
1. Hasil uji t untuk variabel penjualan yaitu nilai thitung > ttabel $/ 33,705>1,98177$ serta nilai signifikan $0,000<$ 0,05 sehingga Ha diterima artinya ada pengaruh penjualan dengan arah positif serta signifikan pada keuntungan bersih perusahaan industri barang konsumsi yang tercatat pada BEI periode 2014-2018.

2. Hasil uji t untuk variabel hutang lancar yaitu nilai thitung > ttabel ataupun 2,896 > 1,98177 serta nilai signifikan $0,005<0,05$ sehingga Ha diterima berarti terdapat pengaruh hutang lancar dengan arah signifikan serta positif pada keuntungan bersih perusahaan industri barang konsumsi yang tercatat pada BEI periode 2014-2018.

3. Hasil uji $t$ untuk variabel modal kerja yaitu nilai thitung $>$ ttabel $/ 4,042>1,98177$ serta nilai signifikan $0,000<$ 0,05 sehingga memiliki arti Ha diterima berarti ada pengaruh modal kerja atas keuntungan bersih perusahaan industri barang konsumsi yang tercatat pada BEI periode 2014-2018.

4. Hasil uji t guna variabel perputaran persediaan yaitu nilai thitung $<$ ttabel ataupun $0,689<1,98177$ serta nilai signifikan 0,492 >0,05 dan kemudian berarti Ho diterima berarti tidak terdapat pengaruh perputaran persediaan pada keuntungan bersih perusahaan industri barang konsumsi yang tercatat pada BEI periode 2014-2018.

Hasil penelitian membuktikan terdapat pengaruh penjualan terhadap laba bersih dimana setiap peningkatan penjualan akan memberikan dampak pada peningkatan laba bersih. Hasil penelitian Muhajir (2020) juga menunjukkan pengaruh penjualan secara signifikan terhadap laba bersih dengan arah positif.Hasil penelitian membuktikan terdapat pengaruh hutang lancar terhadap laba bersih dimana bertambah besar penggunaan hutang akan memberikan manfaat yang meningkatkan keuntungan bersih. Hasil penelitian Adianah (2019) menunjukkan bahwa hutang lancar memiliki pengaruh dengan arah positif terhadap laba bersih. Hasil penelitian dapat membuktikan adanya pengaruh modal kerja terhadap laba bersih. Hasil penelitian Widyamukti dan Wibowo (2018) juga berpengaruh positif signifikan modal kerja atas keuntungan bersih namun tidak sama dengan hasil penelitian Muhajir (2020) yang membuktikan modal kerja tidak memberikan pengaruh atas laba bersih. Hasil penelitian ini tidak bisa menunjukkan terdapatnya pengaruh perputaran persediaan atas laba bersih. Hasil penelitian Mulyana dan Pethy (2018) yaitu perputaran piutang tidak berpengaruh terhadap laba bersih.

\section{SIMPULAN}

1. Penjualan, hutang lancar dan modal kerja secara parsial memberikan pengaruh positif serta signifikan atas laba bersih, dan perputaran persediaan tidak memberikan pengaruh atas keuntungan bersih perusahaan industri barang konsumsi yang tercatat pada BEI tahun 2014-2018.

2. Dengan cara simultan penjualan, hutang lancar, perputaran persediaan, serta modal kerja memberikan pengaruh signifikan atas laba bersih perusahaan industri barang konsumsi yang tercatat pada Bursa Efek Indonesia tahun2014-2018.

\section{DAFTAR PUSTAKA}

Bambang Riyanto. (2011). Dasar-dasar Pembelanjaan Perusahaan. Yogyakarta : BPFE.

Ghozali, Imam. 2013. Aplikasi Analisis Multivariate dengan Program IBM SPSS 21 Update PLS Regresi. Semarang: Badan Penerbit Universitas Diponegoro.

Hani, Syafrida. 2015. Teknik Analisa Laporan Keuangan. Medan: UMSU PRESS.

Nafarin, M. 2013. Penganggaran Perusahaan. Edisi ketiga, Cetakan kedua, Buku 1. Jakarta : Salemba Empat.

Raharjo, Budi. 2016. Sistem informasi Penjualan Bandung : Informatika.

Sugiono. 2012. Memahami Penelitian Kualitatif. Bandung: ALFABETA. 